\title{
Twitter, Mobile Device and Citizen Journalism
}

\author{
Raidah Intizar \\ FISIP, Universitas Islam Makassar, Makassar, Indonesia \\ Corresponding author: raidah.intizar@gmail.com
}

\begin{abstract}
People have been engaged in citizen journalism for a long time, and in the era of internet and communication technology becomes rapidly advanced, the compression and convergence of ICT technology were all combined to support for citizen journalism practice. What is more is Twitter that affords mobility through access from mobile devices is becoming more suitable for citizen journalism compare to other social network platforms. Therefore, we are interested to unravel the phenomenon of Twitter access from mobile device. Is it true that Twitter and mobile device access amplifies citizen journalism engagement? This question was addressed with a quantitative study, and the results indicated that frequent access to Twitter through cell phone did not entirely explain citizen journalism engagement.
\end{abstract}

Keywords—citizen journalism, twitter, mobile device, ICT

\section{INTRODUCTION}

It was early summer 2012 in Cairo when a silent man in beige uniform brought to the middle of a court. As tough as a rock, he sat inside a solid cage. His remaining pride might have scattered due to his situation, but endure it he must, he listened to the verdict from the judge. For all the crimes he committed, the jury sentenced him a life in prison. Both antis and pros of the man were overwhelmed by the outcome. The former wished that it was a dream, while the latter expected that it was a reality. No one would ever believe that he, who had been the most powerful ruler for three decades will be eventually imprisoned by his own people [1][2]. It is a revolution. And people call this revolution and the revolutionary wave that followed in Arab countries, exactly when the spring is in the corner, as "Arab spring”.

Arab spring began with a "tweet", seems metaphorical but it was literally started with tweets. As many mainstream media have posited, social network such as Twitter was a highly essential contributive aspect to the revolution [3]. Tunisian was the first to make use of social network to mobilize mass. Under the tyranny regime for years, Tunisian and Egyptian found a way to resist, which is through social network. After the revolution, there have been demonstrations everywhere using the Net to mobilize movement.

These phenomenon attracted global attention on social network role. Mainstream media coined the phenomenon of social network role assisting the freedom as Facebook or Twitter revolution, they perceive social networks is necessary to the freedom obtained, some others express that this is an extreme result for citizen journalism practice[3].
The phenomenon of ordinary people reporting news and substituting for professional has long been known as citizen journalism, and with the role of social network citizen journalism becomes increasingly prolific. Reference [4] predicts that the development in the Net would result in people invent more ad hoc ways to use the Net, including voluntarily sharing what happened in their surroundings. Even though unintended, people practice citizen journalism. The power of citizen journalism is tremendous, by practicing citizen journalism people could counter mainstream media information because citizen journalist cover a broader sense and offer alternative view to the mainstream media generalization [5][6]; citizen journalism gives propensity to affect the global public opinion, which explained by a tendency of citizen journalist in east hemisphere to use English in their reports [7][5][6]; citizen journalism is a fertile land for alternative surveillance account, as mainstream media oftentimes are unaware of an incident, if not ignoring, citizen journalism media provides means to the citizens to retrieve the most current condition in times of crisis or disaster [4][6]; citizen journalism also a mean to elicit a perfect validation, as citizen journalism is a collaborative work [4][6][8][9] and this is a salient feature that belongs to citizen journalism.

The Net development moderates all the need for citizen journalism engagement, especially Twitter. With regard to its social media predecessor, Twitter has four significant features that made it more suitable for citizen journalism practice. First of all is the micro-blogging feature of Twitter. Twitter allows people to blog in 140 characters, and this characteristic compels Twitter user to focus on what they want to update. Original blogger criticize the feature, because according to them blogging requires a good writing skills and large content as a reflection of one's thought [10]. However, this feature in turn would be utilized by users with or without writing skills to compose a report of an event instantly. Secondly, Twitter is an open communication "Twitter is built on open source software, from the back-end to the front-end...."[11].The inherently open source of Twitter allows people to interact with public figure and organization [12]. While prior emerging social media are more likely to support interpersonal communication, Twitter facilitates open and public communication. Both individual and organization sign up Twitter accounts and are able to interact with each other, subsequently connection and information flow on Twitter is unlimited. In the past, to immediately have a conversation with a parliamentary member was unimaginable. Twitter is the 
first platform to enable such communication. In addition with this function, Twitter amplifies democracy and transparency. Thirdly, twitter also works to filter certain topic, the function is called information filter [13]. Citizen journalism would benefit from information filter, to engage and to advocate a certain event. Lastly, compare to the other social networking platforms, Twitter is more likely to be accessed on mobile devices. As reference [15] states, after Twitter close an agreement with major mobile phone corporation, Twitter access from mobile devices rocketed to 62 percent. The mobile nature of Twitter made it accessible anywhere and anytime.

As mentioned earlier, social network as a result of ICT development, together with compression and convergence of ICT devices have all combined to support for citizen journalism practice. What is more is Twitter is becoming more mobile compare to other social network platforms. Therefore, we are interested to unravel the phenomenon and formulated the following research question:

RQ1:"Do people who access Twitter from cell phones are more likely to engage in citizen journalism on Twitter?”

We formulated our hypothesis, based on the justification we have explained, as follow:

H1: Respondents who frequently access Twitter from a cell phone are more likely to engage in citizen journalism on Twitter.

As a control variable, we also formulated research question regarding Twitter access through computer and laptop, and we expect to find that access through computer and laptop would not trigger citizen journalism engagement in supporting our previous hypothesis. Below are the detailed research questions and hypothesis.

RQ2: "Do people who access Twitter from computer and laptop are more likely to engage in citizen journalism on Twitter?”

H0: People who access Twitter through computer and laptop does not likely to engage in citizen journalism.

\section{RESEARCH METHOD}

\section{A. Design}

We address the research question with a quantitative study. We made an online questionnaire wherein people participate and answer a set of questions regarding their likeliness to report certain event on Twitter, next the participant would rate their frequency of accessing Twitter from a mobile device or a desktop (computer) or a laptop. We also have demographic sets of question.

\section{B. Procedure}

The questionnaires were powered by Qualtrics.com, we made use of Tilburg University Communication and Information Sciences account on the survey resource. The survey was distributed between 5th of June to 19th of June
2013. The participants were limited only to Indonesian who have Twitter accounts. Given that the questionnaire was distributed to Indonesian, Indonesian version of the questionnaire was made available with language switch option on the upper right of the questionnaire. We gathered the respondent mainly by sharing links on social media platforms such as Facebook and Twitter. Family, friends, and colleagues were asked favor to distribute the survey. Indonesian writers, academic community, experts, journalist, were also requested on Twitter to re-tweet the link to the questionnaire.

After a brief introduction about the study and the aim of the study, the respondent immediately directed to the questionnaire. Respondents were exposed to a set of questions on likelihood to tweet in certain situation, such as when respondent in the middle of traffic jam, when they witness a natural disaster, etc. The subsequent question asked them about the frequency of accessing Twitter through mobile devices. The option is limited to five-items Likert scale, starting from never to always. The final part of the questionnaire is demographic questions (gender, age and the highest education they have completed).

\section{Participants}

The questionnaires were made available online from 5th of June to 19th of June. Total respondent is 191 respondents, 62.8 percent $(N=120)$ of which are female with an average age of $22.69(S D=4.12)$. The youngest respondent was 13 years old, and the oldest respondent was 40 years old.

\section{Variables}

In this study, we tried to find significant difference of citizen journalism engagement based on frequency of Twitter access through mobile devices, therefore we have two variables; independent variable which is the frequency of accessing Twitter on mobile devices; and dependent variable which is citizen journalism engagement. The independent variable was measured with a 5-items Likert scale from Never to Always (How do you access twitter usually? From a cell phone; from a computer; from a laptop), and the dependent variable measured with five likelihood questions (Would you tweet if you are in situations below? You are watching a sport match, you are in the middle of a traffic jam, you are witnessing an accident, you are watching a live performance, you are witnessing a natural disaster), we recoded the question as Citizen Journalism Engagement $(\alpha=0.64)$. We guide our reliability value as suggested by a reference [16] which accepted Cronbach $\alpha$ values greater than 0.60 , therefore the reliability for trust is considered as acceptable.

\section{RESULT AND DISCUSSION}

\section{A. Hypothesis testing}

The main objective of this study is to reveal whether citizen journalism engagement amplified by the access of Twitter from mobile device. We have made a measure for citizen journalism engagement by recoding questions on likelihood to tweet certain events, and we asked the respondent frequencies on accessing Twitter from mobile 
devices. We expect to find that frequent Twitter access from mobile device would result in greater engagement in citizen journalism.

The proposed hypothesis is that respondents who access Twitter from a cell phone are more likely to engage in citizen journalism on Twitter.

We tested the normality for the frequency measure and we found out that for group of respondent who sometimes access Twitter from a cell phone, and for group that always access Twitter from a cell phone violated the assumption of normality $(D(30)=0.175, \quad p=0.020$, and $D(69)=0.150, \quad p=0.001$ respectively). Nevertheless, the following hypothesis was tested:

H1: Respondents who frequently access Twitter from a cell phone are more likely to engage in citizen journalism on Twitter.

A one way Anova was executed to test the hypothesis and the result showed a relation between frequency of accessing Twitter from a cell phone to citizen journalism practice, $F(2,186)=2.76, p=0.029$. Post hoc using Bonferroni indicated that only those who always access Twitter from cell phone $(M=3.71, S D=0.79)$ more likely to practice citizen journalism than those who sometimes access Twitter from cell phone $(M=$ $3.20, S D=0.88)$. However for those who rarely access Twitter from cell phone ( $M=3.56, S D=0.43)$, and those who most of the time access Twitter from cell phone $(M=3.43, S D=.75)$ did not differ significantly in citizen journalism practice to any other group. Herewith, our hypothesis is partially supported.

We further tested our second hypothesis as follow:

H0: Accessing Twitter through computer and laptop does not triggering citizen journalism engagement.

Two of one-way Anova were performed in order to prove the hypothesis and the result showed no relation between frequency of accessing Twitter from a computer or a laptop with citizen journalism engagement $F(4,186)=0.302, p=$ 0.876 , and $F(4,186)=1.209, p=0.308$ respectively. Therefore, our null hypothesis is supported.

\section{B. Discussion}

Our hypothesis concerned about Twitter access devices, and if people who access Twitter from a cell phone are more likely to engage in citizen journalism. We expect to find that people who frequently access Twitter from cell phone are indeed reported more likelihood to engage in citizen journalism on Twitter. Cell phone was chosen because first it represents compression and convergence in ICT as noted earlier; second, Twitter has an inherent mobile character which means it is the most suitable to access from a cell phone. If the hypothesis is proved, it should support the growing assumption that ICT advances and social network advances are positively correlated to the increase in citizen journalism practice.
We found that our hypothesis is partially supported. Frequent access to Twitter from mobile devices, particularly cell phone, did not completely in line with the likelihood to engage in citizen journalism. Moreover our null hypothesis is supported as we find that frequent Twitter access through computer and laptop did not amplifies citizen journalism engagement.

\section{Limitations}

There might be other variables aside from Twitter access from mobile devices that could trigger engagement in citizen journalism. People should refer to their motivation and condition. It should also be noted that we limit our options to only five events (watching a sport match, in the middle of a traffic jam, witnessing an accident, watching a live performance, witnessing a natural disaster). Although the measure found to be of reliable, the measure limits our respondent into rating their likelihood. Moreover, according to studies [4][6] citizen journalism media provides means to the citizens to retrieve the most current condition in times of crisis or disaster, our options did not quite provide events of crisis or disaster.

\section{CONCLUSION}

As information and communication technology advances, affordance that used to be exclusively belong to one group now is now equally distributed. With a cell phone, people are able to execute actions such as recording and capturing image, which in the past might require more than one device. The advancement in internet has also enabled anyone to do anything, old conventions thus are being challenged. One of the old conventions is the convention in acquiring news. With social network platforms, especially Twitter, people are able to acquire news on their mobile devices, and are able to also report happenings on their surroundings instantly. What we were interested to know was how Twitter access from mobile device affect the citizen journalism engagement, although we find that we cannot scaffold the hypothesis, we predicted that this is due to the measure. We are still convinced that ICT development did contribute to high engagement on citizen journalism.

\section{REFERENCES}

[1] D.D. Kirkpatrick, (11 February 2011). Egypt Erupts in Jubilation as Mubarak Steps Down. Retrieved from http://www.nytimes.com/

[2] N. Meo, (2 June 2012). From pharaoh to prisoner: Hosni Mubarak given life sentence for murder. Retrieved from http://www.telegraph.co.uk/news/worldnews/africaandindianocean/egyp t/9307872/From-pharaoh-to-prisoner-Hosni-Mubarak-given-lifesentence-for-murder.html

[3] A.A. Olorunnisola, B.L. Martin, (2012). Influences of media on social movements: Problematizing hyperbolic inferences about impacts. Telematics and Informatics.30 (2013).275-288. Retrieved from http://dx.doi.org/10.1016/j.tele.2012.02.005

[4] C. Shirky, (2010). Cognitive surplus: how technology makes consumer into collaborators. London: Penguin. ISBN: 978-0-14-311958-6 http://etd.ohiolink.edu/view.cgi?acc\%5Fnum=osu1275406094

[5] M. Wall, (2009) The taming of the warblogs: citizen journalism and the war in Iraq. In S. Allan \& E. Thorson. Citizen journalism: global 
perspective. 33-42. New York: Peter Lang Publishing. ISBN: 978-14331-0295-0

[6] H. Zayyan, and C. Carter, (2009). Human rights and wrongs: blogging news of everyday life in Palestine. In S. Allan \& E. Thorson. Citizen journalism: global perspective. 85-94. New York: Peter Lang Publishing. ISBN: 978-1-4331-0295-0

[7] S. Allan, (2009). Histories of citizen journalism.In S. Allan \& E. Thorson. Citizen journalism: global perspective. 17-32. New York: Peter Lang Publishing. ISBN: 978-1-4331-0295-0

[8] F. Vis, (2009).Wikinews reporting of Hurricane Katrina.In S. Allan \& E. Thorson.Citizen journalism: global perspective. 65-74. New York: Peter Lang Publishing. ISBN: 978-1-4331-0295-0

[9] P. Bradshaw, (2009). Wiki journalism.In S. Allan \& E. Thorson.Citizen journalism: global perspective. 243-254. New York: Peter Lang Publishing. ISBN: 978-1-4331-0295-0
[10] B. Shriram, (2010). Short text classification in twitter to improve information filtering.(Master's Thesis). Retrieved from

[11] Twitter (2013). About. Retrieved from https://twitter.com/about

[12] H. Kwak, C. Lee, H. Park, \& S. Moon, (2010, April 26-30). What is Twitter, a social network or a news media?.Presented at the 2010 International World Wide Web Conference, Raleigh, North Carolina.

[13] P. Nauts, “Business and the web”.Evolution of Internet.Cobbenhagen building, Tilburg. 8 February 2013. Lecture.

[14] E. William, (3 September 2010). The evolving ecosystem. Retrieved from http://blog.twitter.com

[15] J.P. Robinson, P.R. Shaver, \& L.S. Wrightsman, (1991).Measures of personality and social psychological attitudes: Volume 1. California: Elsevier. Retrieved from: http://books.google.com 